\title{
Private Colleges Market-Oriented Incentive Mechanism of Teacher Compensation Characteristics Research
}

\author{
Han Xinliang \\ Department of electronic commerce, \\ Sichuan vocational college of science and technology, \\ Chengdu 610031, China \\ 1466155063@qq.com
}

\begin{abstract}
The market of salary system reform is an important part of the non-governmental university internal management system reform. Currently, many problems in salary system of colleges: the lack of efficiency and fair, the lack of individual incentive, salary system reform lags behind; the fundamental reason is the lack of marketization. It is the key point of college teacher development. For the construction of the education fair environment, for the sake of stable teacher troop, enhance the level of private universities and private colleges and universities teachers' compensation system should strengthen market regulation, allowance with the floating market, and correctly grasp the fixed part of the compensation and floating proportion relations. Performance salary reform should step up spending, appropriate increase teachers' salaries. Moderate introducing market mechanism, improve the distribution of satisfaction; improve the teachers' welfare supporting system construction, etc. Need to be run by the local design should be based on the position salary system of colleges and universities; Improve the guarantee mechanism of private colleges and universities teachers' compensation system. Set up a scientific system of performance audit, and improve the proportion of performance pay in overall compensation; fully considering the subject differences and the different characteristics of the academic work, and run by the local college teachers' professional characteristics.
\end{abstract}

Keywords-teachers' salary; market-based degree; incentive salary; pay delay distribution

\section{INTRODUCTION}

Private colleges teachers cannot enjoy treatment of "system", also did not enjoy market fair treatment, generally low wages, lack of rationality, so as to loss of good teachers, teachers' team is not stable, and operating conditions is worse. Due to the poor foundation within the system of private colleges, school funding is a single, less money, needs to have incentive compensation system to attract excellent teachers, to development faculty. To studies teacher pay market-oriented incentive mechanism, according with the characteristics of non-governmental university teachers' salary system, it is necessary to the development of private schools.[1]

Marketization is the competition means of evolution in the open market taking market demand as the guidance, it is also

Sponsor: The natural science foundation of Science and Technology Agency of Sichuan province, (2014FZ0112). the means of sufficient and reasonable configuration of resources[2], and the mechanism of efficiency maximization goal. Market-based degree of teachers' salary system of colleges and universities in our country is poor, lacking of external competitiveness and internal incentive and there are defects of short-term in its incentive mechanism, It will be disadvantage to arouse teachers team. [3] At present most research is about public university teachers' salary system, there is few study for private colleges teachers pay problems and countermeasures. In order to make up for the deficiency of the research of private colleges teachers in our country, and the study of this special group run by the local college teachers, it has important practical and significance to enrich the exist management theory. [4-5]

In this paper, by analyzing the marketization of private colleges pay system, consult to overseas researching achievements of university teachers' salary incentive theory and enterprise compensation mode, trying to explore a suitable private colleges pay, and reasonable compensation system, proposed the present salary reform, stage in our country run by the local college teachers' performance, should introducing market mechanism, increase the funds investment, improving teachers' salaries, correctly grasping the fixed part of the compensation and floating proportion relations.

\section{The MARKET PROBLEM OF COMPENSATION SySTEM OF PRIVATE UNIVERSITIES}

\section{A. Market Competition and Fairness}

When designing compensation must follow certain principles, these principles include the strategic orientation, economy, manifest the value of employees, incentive, relatively fair and external competitiveness, etc. External competitive principles: must consider the market industry pay compensation and competitors pay levels, to ensure that the enterprises pay levels have a certain competitiveness in the market, can fully needed to attract and retain the key personnel for the enterprise development strategy. Principle of relative fair (internal consistency) is Smith fair theory in the application of compensation design. It emphasizes that enterprises in the design of platforms should be a bowl of water when you pay. Internal consistency principle includes 
several aspects. It is horizontal fairness, namely enterprise between all employees compensation standard, the scale should be consistent; Second, vertical fairness, namely enterprise must be considered when designing compensation the continuity of history, input-output ratio and an employee of the past and the future should be basically is consistent, but also should be increased.

The establishment of private universities of post allowance, made a progress towards allocation of factor of the capital, but has not formed the perfect system. Post allowance also has the flavor of egalitarianism, on the one hand, consider the allowance leaning to the rate of return high teaching jobs, on the other hand to juggle all aspects of the opinion, consider investors profit preferences, such as reduce the wage gap, reduce internal contradictions. Private colleges pay status quo is that the high does not reach the designated position, that the low does not drop down. Distribution according to work are not assigned by post. Someone on-the-job without working are need reason to deal with.

Reasonable income gap is a benefit to reflect the distribution principle of the pledge "to calculate optimal law", to break the equalitarianism, form a competitive incentive mechanism. However, if the gap is too large, deviated from the difference of labor, as well as egalitarianism, will dampen the enthusiasm of people, cause people psychological imbalance, a negative impact on the school's stability and development. So, how to deal with the relationship between competition and fairness problem, is one of the problems in the reform of internal distribution system of private colleges.

\section{B. The Problem of Insufficient Market Incentives}

Performance pay is the core of which teachers' salary level changes over with personal and team performance. Private colleges performance: teachers for the school valuable work performance, schools that match the culture and values, actualizing the strategy of school goals. Therefore, performance pay and salary have different emphases. Relatively, offer basic salary and performance pay emphasis on incentives. When teacher performance can get a fair evaluation and get corresponding remuneration to, the teachers, the psychological demand for fairness and a sense of achievement can be satisfied at the same time.

In private colleges, teachers pay Suggestions according to the principal financial resources, teachers by the school board decided to wage levels, wage and the extent of automatic annual wage increases, and determine the incentive to increase wages, holiday pay, pensions and various standards and distribute benefits. In fact, is a standard is high, low income. For most private colleges teachers, they all rely on this to maintain life.

Private colleges do not pay much attention to teachers' incentives, performance pay share is too small, or not at all. Objective because of the system problem, less funds, poor foundation, considering the characteristics of their own development and the ability to pay, one thousand party hundreds of compression. Human reason is that the investors profit, in order to increase and expand the investment, the sustainable development of enterprise. A private colleges of young teachers work very hard, while have a class, while research, also shoulders the heavy student management work, performance pay and the contrast of adjacent public schools are shown in table 1-1: class fees of $0.5,0.05$ reward, the paper subject awards 0.05 .No, the scientific research project funds allowance, lack of performance pay, more do not stem, very unfavorable to mobilize teachers' initiatives.

\section{The Problem of Private Colleges Pay Market-oriented}

The existing income distribution system of deep-seated contradictions and problems need to be further solved, some problems have appeared. Development history in China, for example, private colleges but 10 to 20 years, compared with most public schools, various conditions is poorer, insufficient funds, the work is difficult. Should do hard work with high salary incentive teacher, however, it is not down.

College teachers pay level positioning on the low side, external talent market competitiveness. Run by the local university teachers' salary system belongs to the investors, small pay levels affected by market competition mechanism, some scholars through statistical yearbook data of comparative analysis, concluded that the income level of university teachers in a relatively low position in the industry. Therefore, external competitiveness of China's university teachers' salary is not enough, is not conducive to attract talented people to join, to devoted himself to the cause of higher education.

University teachers' salary system centered on duties and qualifications, lack of internal incentive. At present, the college teachers national wage based primarily on position, office term, length of service and education, allowances and subsidies and campus distributions are mostly related to the above factors, lead to pay distribution considering the individual ability and the performance is not enough, so the internal teachers lack of incentive.

Salary system in the existing flaws of short-term and shortterm incentive mechanism, make teachers' academic utilitarian. At present, some colleges and universities on the distribution of allowances and subsidies in the school is equipped with a certain incentive mechanism, such as scientific research achievement awards, super workload subsidies, etc. Salary system is not conducive to stimulate teachers' team work spirit Compensation relies mainly on the promotion of growth, the teachers pay more attention to their individual skills and personal achievements of output, so it is difficult to guide teachers to knowledge sharing and teamwork.

Distribution system can really reflect the talent value hasn't really set up; To a certain extent, the new pot exists, the overall income level has improved, excellent talent of salary is not high enough, attract the best talent strength is not enough; On the other hand, are not suitable for work flow not to go out at school, encourage the rational flow of talent mechanism has not been formed. 


\section{TEACHERS PAY MARKET EFFECTIVE MEASURES}

\section{A. Private Colleges Market-oriented Vocational Characteristics of Salary System}

The impetus of the economic growth in China is not material resources and human resources, it is science and education in the implementation of the strategy, seek from a big population of human resources in the process of power shift, private colleges and the teachers ought to assume considerable responsibility. Private colleges of human resource management function is to support the development strategy of private colleges, rather than the functions of archives management and identity management. Run by the local characteristics of university teachers' career perspective there are three kinds of model[4]: one is professional characteristics in the theory of compensating wage difference; Second is the professional characteristics of Snell model; To change the current private universities human resources functions, make private university human resources management system service for private universities to achieve competitive advantage.

\section{B. To Improve the Proportion of Performance Pay in Overall Compensation}

At present, quite a number of private colleges has not yet set up a performance pay system, part of the system of private colleges is in start level, even if the performance pay part of private colleges, the proportion is quite small.

Private colleges, researchers put forward three yuan compensation structure performance pay in overall compensation should be accounted for in the share of: basic salary, post allowance, and the proportion of the post merit pay for: $40 \%, 10 \%, 50 \%$ more appropriate. Concrete proportion of performance pay for how many, but also according to the development strategy of schools, financial aspects of the specific planning level, not do a unified regulation, but its share in principle should be able to have incentive effect, play/distribution according to work, to inspire potential, to promote the role of competition, or it is ineffective.

To raise the proportion of performance pay in overall compensation at the same time, also should establish scientific performance appraisal system. Only do a good job in the performance appraisal can say truly achieve the distribution according to work, can truly play the role of incentive groups and individuals.

\section{Allocate More Delay Compensation Share in the Overall Compensation}

Private colleges teachers' compensation system in the delayed payment system there are two main function: establish long-term incentive mechanism; Establishing social risk sharing mechanism, namely teachers' welfare and security program. Delay distribution in the form of a constraints: constraints such as present value, which provides the present value of the flow of wages for the internal market staff, at least equal to the external labor market equilibrium of similar employee wages the present value of the flow, or employees will have a tendency to move, difficult to retain the talent needed to. However, deferred payment and is associated with the expected discount rate of employees, when employees expected, the higher the discount rate is the greater the deferred payment amount. So, the organization must grasp strength, because delay distribution incentive will have a certain strength to achieve the desired effect, strength is too small, cannot achieve the effect; Too much, the economic capacity to bear. Therefore, the organization should be in the appropriate incentive strength and can withstand strike a balance between economic ability to pay.

Introducing delay distribution system is highly advantageous for the university's human resources strategy. On the one hand, the money is actually delay distribution is still the teachers deserve compensation, for teachers, this is a pay delay, teachers at a relatively low salary levels, in exchange for their retirement pension rights, or a return in a few years. If teachers leave their work of private colleges, he accumulated in the deferred account assets may be deprived of part. Deferred payment mechanism as a kind of implicit contracts. Suppresses the teachers job motivation. In the knowledge economic times, more competitive, risks and opportunities coexist, scope and depth of the social risk are deepened.

\section{Marketization Compensation System of SECURity} METHODS

\section{A. The Marketization Compensation SNELL "Commitment"}

According to the university teachers' professional features, establish compensation management model based on classification of talent. According to the American professor Scott, schneier (Scoot a. Snell) put forward "the commitment of the core of human resources management core model", namely the Snell model, according to its strategic importance of human capital and scarcity is different, can be divided into core human capital, the general human capital, human capital and special human capital four classes. Of different human capital should adopt different compensation management model, the essence of strategic human resource management and the key is the core of human resource management. We should according to the strategic value of school teachers and classify the scarcity in the Labour market, for different types of talent for different compensation management. Of core talents than the Labour market average wages and higher benefits, as the knowledge, experience and qualification rate; For ordinary people to give the market wage rates, paid for performance; For auxiliary personnel temporary contracts signed by the hour or paid; Give special talents on the basis of the contract of wages, paid for knowledge.

SNELL in terms of income distribution model emphasizes the following three points: one is the high wages, the wages higher than the market average, it is likely in the talent market competition. Keep the core the wage rate is competitive in the market of human resources is critical. On the one hand, higher wages to attract external human resources; On the other hand high wages can effectively keep the enterprise the core of human resources; The second is based on the ability of the income distribution system: according to the views of SNELL 
model, core human resources compensation design should be mainly based on core competence. Equity sharing has become a first-class enterprise attract and retain talent "magnetic field". Stock options are higher than high prize attractive, not only is that it itself is a kind of material incentives, more important is a spiritual incentive, namely personal fate and organization on a rope tied to the future.

\section{B. Considering the Market Characteristics of Academic Profession}

Academic profession is refers to the category of social work practitioners engaged in. International studies university teachers are under the framework of academic profession, to study from the perspective of vocational college teachers' appointment, promotion, compensation, etc. Academic profession market flow is one of the characteristics of modern university system, also is the advantage of private colleges education system. Private colleges is not to reduce the liquidity, but to fundamentally improve the state of private colleges academic profession, flow from the marketization of retaining good teachers.

Teacher is the main part of the private universities of labor resources, the general has a highly educated, high knowledge, knowledge in instead of money. As with other professions, needs to inspire teachers' working enthusiasm and working enthusiasm. Compensation is not only a necessary economic returns, and expressed the schools for teachers' work of a value.

The market value of the individual human resource is mainly decided by the individual of their own conditions, and human resources of the market value of the individual to achieve mainly decided by the market conditions. Establishing scientific evaluation mechanism. Scientific evaluation system, the reasonable evaluation of teachers' job performance, reasonable evaluation of market value. Fair evaluation of individual teachers' knowledge, ability, moral character and work performance, market value, found the gap between the teachers, the teaching effect of a good teacher must vigorously, has a special contribution shall be amply rewarded; To adjust to the bigger difference of market value. School only correctly by means of marketization of the scientific assessment, adjust the teacher pay, to make teachers towards a healthy and stable development.

\section{Market-oriented Incentive Pay System Security Method}

People always put the condition of equal effort compared with remuneration, within the scope of the market, to maintain the fairness on the distribution, to arouse the enthusiasm of work. Pay market surveys to ensure compensation with market competitiveness. Private colleges in determining compensation, need to refer to the Labour market pay levels. Investigation has competition relationship between private colleges, different pay structure comparison, last year's salary increase, bonus and welfare conditions, different position and different levels of salary data, long-term incentive measures and future compensation movements, etc. According to the plot of compensation, the compensation survey data to determine the private colleges pay levels compared to the same place. Position relative value evaluation of interior guarantee compensation fairness. Position relative value assessment, it is more private colleges internal to the relative importance of each job, get job grade sequence; Second is to build a unified position relative value evaluation criteria, comparable between different positions, and to lay a foundation in order to ensure the fairness of compensation. There are many methods of position relative value evaluation, relatively popular in the international such as HAY and CRG [2], are used to quantify the position relative value assessment method.

In short, determine the compensation levels of private colleges, private colleges need to external market conditions, profit ability, the ability to pay for evaluation. In this way can make the system stability, competition and incentive. In order to ensure the compensation system of marketization, the compensation adjustment and correction on a regular basis.

\section{CONCLUSION}

Compensation system is directly related to the development of the teachers, decides the rise and fall success or failure of the school development. Human resource is one of the most important resources in the construction of development of private colleges, teachers team construction is the first priority of the school. Compensation management is one of the most basic functions of management system, directly involves the immediate interests of the all teachers and staff, directly related to the allocation of resources of institutions of higher learning affects the efficiency of the institutions of higher learning. How to balance fairness and efficiency in compensation management, how to mobilize and exert the enthusiasm and creativity of staff is of great significance. Especially in the current in the process of the personnel system reform continued to deepen, gradually expand the talent market effect, the education fair process is accelerated, private colleges appeared on the compensation management of many different industry, different from other units of the new situation and new problems, we urgently need to set up scientific compensation system, make compensation leveraged, become the positive factors of development and construction in schools.

Author introduction: Han Xinliang, male, was born in 1966, Ph.D., professor. Main research direction for the human resource management, intelligent optimization control algorithm. He has published over 20 papers. I am responsible for provincial scientific research projects.

\section{REFERENCES}

[1] ya-man Lai. American college teachers pay external competitiveness analysis and revelation. [J]. Journal of tsinghua university education research. 2008, 6 .

[2] Michael.H.Moskow Public Policy and Central Counterparty Clearing , Academic journal article from Economic Perspectives, Vol. 30,No.4,2006.

[3] Karacadag, Taylor, The New Capital Adequacy Framework, Institutional Constraints and Incentive Structures, IMF Working Paper No. 00/93,2006.6. 
[4] RuanBaiRong Song Jinzhou. Relationship of the trust of the non-profit organizations and government departments in $\mathrm{m}$. journal of chengdu administration college, 2012 (05).
[5] hai-bin Zhang. Under the incentive compatibility perspective of university internal governance $[\mathrm{J}]$. Journal of education development research, 2012 (01) : 75-79. 